\title{
The Assessment of Groundwater Vulnerability towards Contamination using the DRASTIC and NV Indexes in Banjarbaru City, South Borneo, Indonesia
}

\author{
Firza Syarifa Zahra ${ }^{1}$ and Thomas Triadi Putranto ${ }^{2^{*}}$ \\ ${ }^{1}$ Graduate School of Environmental Science, Diponegoro University, Indonesia \\ ${ }^{2}$ Geological Engineering Department, Diponegoro University, Indonesia
}

Received: 2021-08-04 Accapted: 2021-11-05

Keywords:

groundwater vulnerability; contamination; DRASTIC; NV; nitrate and nitrite

Correspondent email: putranto@ft.undip.ac.id

\begin{abstract}
The current excessive use of groundwater is exacerbated by human activities, which directly or indirectly trigger surface pollution and gradually affect to the subsurface, including groundwater. Indonesia is one of the developing countries that encounter these obstacles, specifically Banjarbaru City in South Kalimantan Province and its surroundings. Hence, proper management is needed to maintain the sustainable function of groundwater, such as by determining its vulnerability index to pollution. This study used geospatial analysis to determine the intrinsic and extrinsic vulnerability of groundwater via the DRASTIC and NV index methods, respectively, through visual representations on a map. The validation involved the distribution of nitrate and nitrite values to review the relationship between vulnerability levels and the presence of anthropogenic influences. Subsequently, the results of the DRASTIC method showed that the study area is included in three vulnerability indexes, namely low (95-120), medium (120-160), and high (160-186). The NV method further indicated that the groundwater vulnerability indices are divided into four, namely very low (21.2-70), low (70-110), moderate (110-150), and high (150-186). Based on the results, the use of specific vulnerabilities was considered more effective than the intrinsic technique in determining the vulnerability index because the NV method considers land use as a parameter to provide more detailed outcomes.
\end{abstract}

Q2021 by the authors. Licensee Indonesian Journal of Geography, Indonesia.

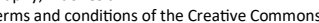

Attribution(CC BY NC) licensehttps://creativecommons.org/licenses/by-nc/4.0/.

\section{Introduction}

Water is a basic need for living things and a source of life for humans. Although this highlights the importance of the availability of groundwater as it is a source of freshwater, its quantity and amount are decreasing daily (Alexander et al., 2017). Inadequate water supply is one of the major challenges in developing countries (Sorlini et al., 2013), as well as the insufficient quality of groundwater, which is a source of clean water. Hence, the poor groundwater quality is a huge problem (Miglietta et al., 2017), including in the study area selected. Groundwater availability is seriously affected by overexploitation, pollution, and climate change (Taylor et al., 2013; Gorelick and Zheng, 2015; Lasagna et al., 2019; Lasagna et al., 2020; Grappein et al., 2021). Besides these problems, many factors influence the decline in quantity and quality, including excessive groundwater extraction and human activity (Putranto and Syah, 2018).

The decrease in groundwater quality can occur due to pollution, which can be described as the poor of a state due to the entry of pollutants (Palar, 2004). Groundwater pollution is a result of several factors, including human activities (Mohammad, 2017), such as pesticide usage in agriculture, household waste, or industrial activities (Kesuma et al., 2017). This contamination often occurs in areas with high population density, industries, and agricultural activities, where it is frequently used as a freshwater source.
Consequently, assessments to prevent contamination are more effective than improving the quality of polluted groundwater (Machdar et al., 2018). Vulnerability is an intrinsic or natural characteristic of groundwater that depends on the system's sensitivity to natural and/or human impacts (Hendrayana, 2011). It is defined as the risk of pollution due to the potential impact of land use. As a result, assessments show that the protection provided by the environment varies across locations (Abdullahi, 2009). Groundwater vulnerability comprises two main ideas, namely intrinsic vulnerability, which is based on an area's hydrogeological characteristics and geological conditions. This aspect depends on three main factors, namely the absorption process and travel time of fluid contaminants, their flow dynamics in the saturated zone, and the concentration of the remaining contaminants upon reaching this zone (Maria, 2018). The second aspect is the specific vulnerability, which refers to the vulnerability of groundwater to specific contaminants generated by human activities.

The intrinsic vulnerability method most often used is the DRASTIC index, initially introduced by the United States Environmental Protection Agency (USEPA) (Aller et al., 1987). Conversely, there are many specific vulnerability methods, including the NV index, which is considered capable of producing a higher level of accuracy with a focus on nitrate as a pollutant (Martinez-Bastilda et al., 2010). 
Shallow groundwater is more easily contaminated than the deep equivalents (Putranto and Kuswoyo, 2008; Putranto et al., 2016), thereby necessitating the use of groundwater vulnerability maps to highlight pollution and as a reference for management in an area to obtain sustainable benefits. Therefore, this study aims to determine and compare the results of the level of groundwater vulnerability to pollution using two methods, namely the DRASTIC index and Nitrate Vulnerability (NV).

Generally, several factors influence groundwater quality, such as geological conditions, lithology, soil type, aquifer properties, and others (Jahanshahi and Zare, 2016). It is also affected by human activities, such as industrial, agricultural, and household processes (Papainoannou et al., 2006). Therefore, quality assessments aim to determine changes in groundwater quality due to interactions between water and rocks or the influence of human or anthropogenic activities (Sadashiyaiah et al., 2008).

This study was located in Banjarbaru City of South Kalimantan Province, and its surroundings and the purpose was based on a fairly complex problem related to groundwater pollution that has not been extensively examined. The latest and most recent study or information related to pollution conditions in the area emerged in 2018 from local news. According to the reports, the condition of water in the area had been contaminated by the shallow storage position of a septic tank close to the groundwater well, which made contamination easy. Although there are no specific scientific investigations, have been conducted, resulting in a study gap, hydrogeological assessments, actions, and evaluations related to groundwater vulnerability are being conducted. This suggests that related investigations are in progress to uncover the problem of groundwater pollution at the most superficial level in the

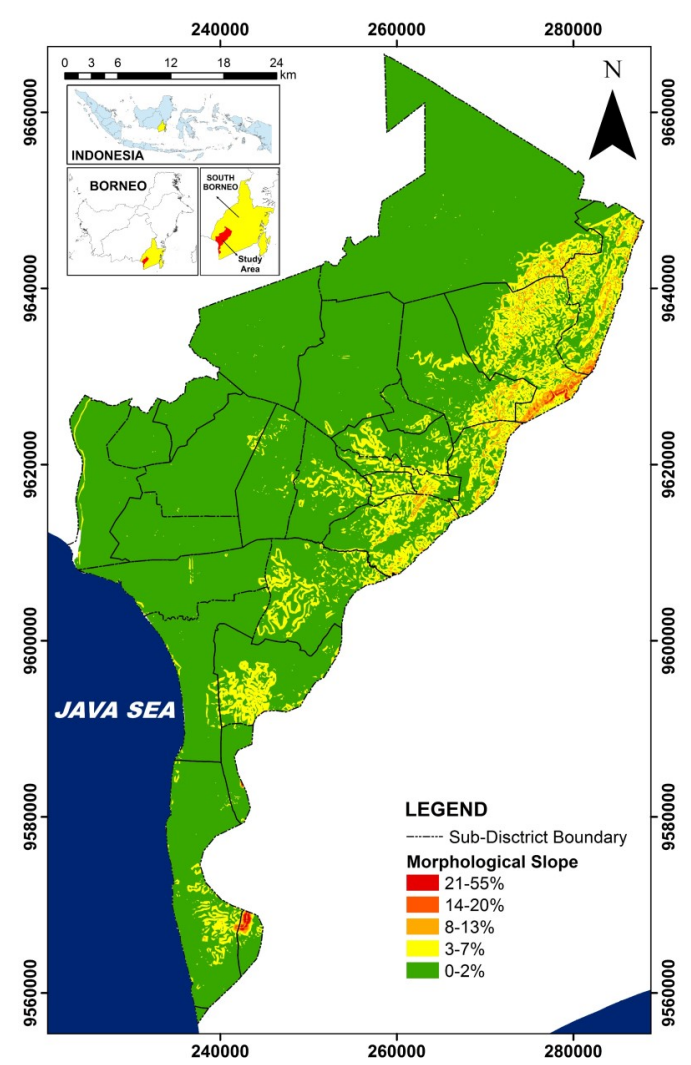

Figure 1. Morphological map focus areas as a starting point for further studies. Consequently, the DRASTIC method and NV Index with nitrite-nitrate tracer were selected as potential bases to explain the vulnerability conditions in the study area. Since these methods can uncover natural and artificial or anthropogenic events related to the groundwater vulnerability conditions, the findings can be applied to other distinct and variable areas around the globe.

\section{Methods}

\section{Site Descriptions}

This study was conducted in Banjarbaru city and its surroundings. The boundaries of this location were between 222699 - $288067 \mathrm{~m}$ (Easting) / $3^{0}$ '48 "- $4^{0} 0^{\prime} 36^{\prime \prime}$ and 9666610 - 9556512 m (Northing) / $114^{0} 30$ ' 19 "- 115 05" 28 ". Based on Zuidam's classification (Zuidam, 1983), the geomorphic condition of this area consists of a $0.03 \%$ distribution of broken hills with a slope gradient of $21-55 \%$. The morphology also comprises $0.11 \%$ and $0.63 \%$ undulating hills with $14-20 \%$ and $8-13 \%$ slope gradients, respectively. Some undulating slope units are spread at every district on the south, central, and upwards to the northeast with a $7.20 \%$ distribution and a slope gradient of 3-7\%. In addition, almost the entire area, specifically $92.03 \%$, is covered by plains with a slope of approximately up $2 \%$, as shown in Table 1 and Figure 1.

Meanwhile, the regional geology map sheet of Banjarmasin with a scale of 1:250,000 (Heryanto and Sikumbang, 1994) shown in Figure 2 indicates that the study area contains several rock formations. The sequence from the oldest to the youngest is Early Cretaceous Gabbro (Mgb), Diabase (Mdb), Pudak (Kap), Pitanak (Kvpi), Keramaian (Kak), Tanjung (Tet), Berai (Tomb), Warukin (Tmw), Dahor Formations (TQd), and Alluvium Deposits (Qa).

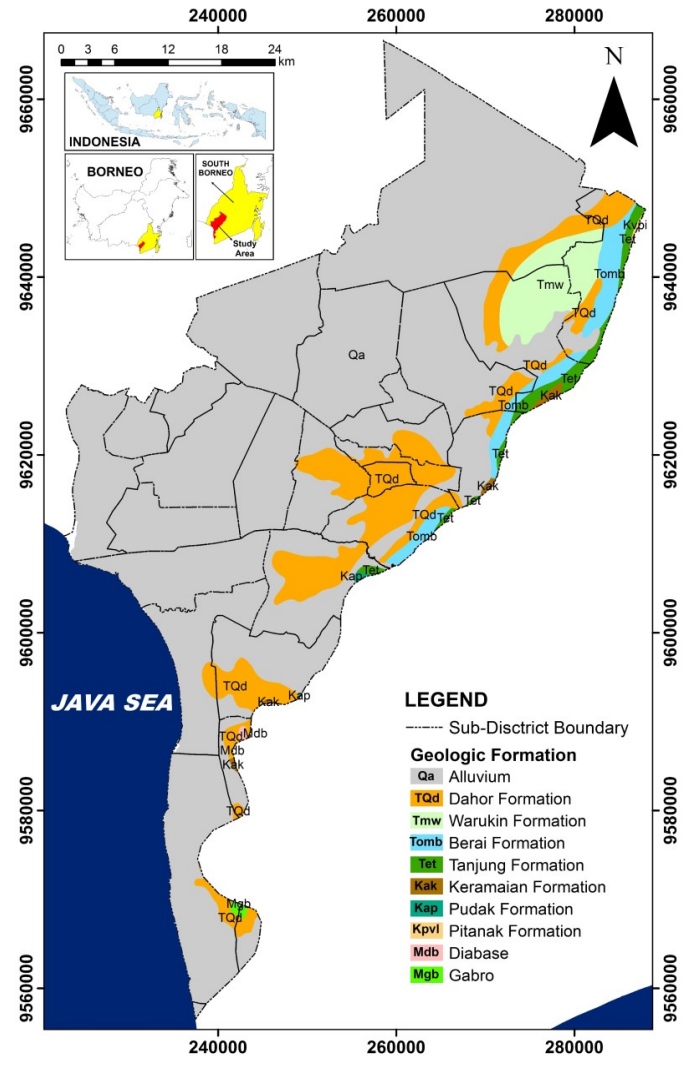

Figure 2. Geological map 
Materials

This primary and secondary or supporting data employed were obtained directly at the study area. The secondary data comprised information concerning precipitation relating to the recharge value, soil typification, topography, and land use data. Subsequently, the precipitation and temperature data were used to determine the recharge value generated from the regional data of the Central Bureau of Statistics in Banjarbaru City from 2015 to 2021. Recharge data, as employed in this study, is influenced by several factors, such as hydrometeorology, geology, distance rainfall, topographic slope, and soil permeability (Li and Merchant, 2013). Generally, water carries pollutants to aquifers during the infiltration process, resulting in groundwater contamination (Civita and DeRegibus, 1995). The soil type data, which were used to determine soil media parameters and the impact of the vadose zone, were obtained from the secondary data acquired from the Regional Development Planning Agency of South Kalimantan Province and based on considerations of the geological condition. In addition, the digital elevation model (DEM) data for the topographic and morphologic assessment were acquired from the DEMNAS site at a spatial resolution around $0.5 \mathrm{~m}$. This was used to determine the topography of the study area, while the land use data was acquired from the Indonesian geospatial information bureau (BIG).

Meanwhile, the primary data was obtained directly from the field and included the groundwater quantity, the result of geoelectrical acquisitions, and pumping test data. The information acquired from groundwater quantity, specifically coordinates, depth, and height, was collected by on-site measurement with water level tools combined with a GPS tracker. Geoelectrical data acquired with

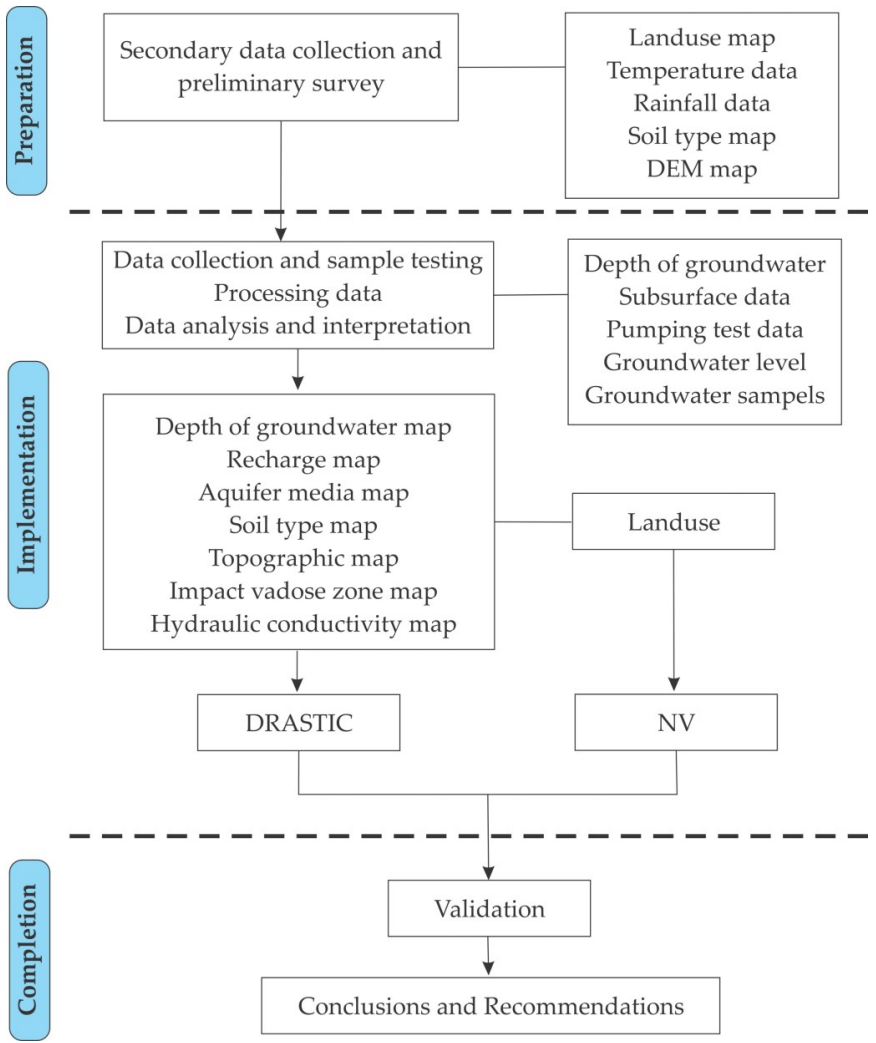

Figure 3. Flow diagram
Schlumberger methods were processed into subsurface data for generating aquifer information, particularly the lithology type and distribution. Conversely, the pumping test data in the unconfined aquifer or based on the dug well was generated from on-site acquisitions using the Neuman Fitting Curve method to determine the hydraulic conductivity values. All the previous primary and secondary data were processed separately but later overlayed for DRASTIC methods.

As shown in Figure 3, this study was divided into 3 stages, namely the preliminary, the observation, and the data analysis stages. The preliminary stage was conducted via a literature study using references about the geological and hydrogeological conditions from previous investigations. Then, the field observation stage was performed by collecting primary data, while field data retrieval involved groundwater condition data, geoelectrical survey, pumping test, and groundwater sampling. According to Figure 4, several data were collected from different Points of Interest (POI) in the observation stage, including 150 dug wells, as well as 11 resistivity surveys and 10 pumping test points.

The distribution of selected locations for groundwater sampling, geoelectrical, and pumping tests were determined by the different types of the region's geological and hydrogeological conditions. Subsequently, 10 groundwater samples were selected from the well and analyzed in the laboratory for groundwater quality, specifically nitrate and nitrite. Although the study budget limited the number of samples collected, the distribution and consideration of the sampling location were selected carefully to minimize the problems. The stages of data analysis were conducted using some applications, namely Excel 2010, Progress, Surfer 11, and ArcGIS 10.3.1 software.

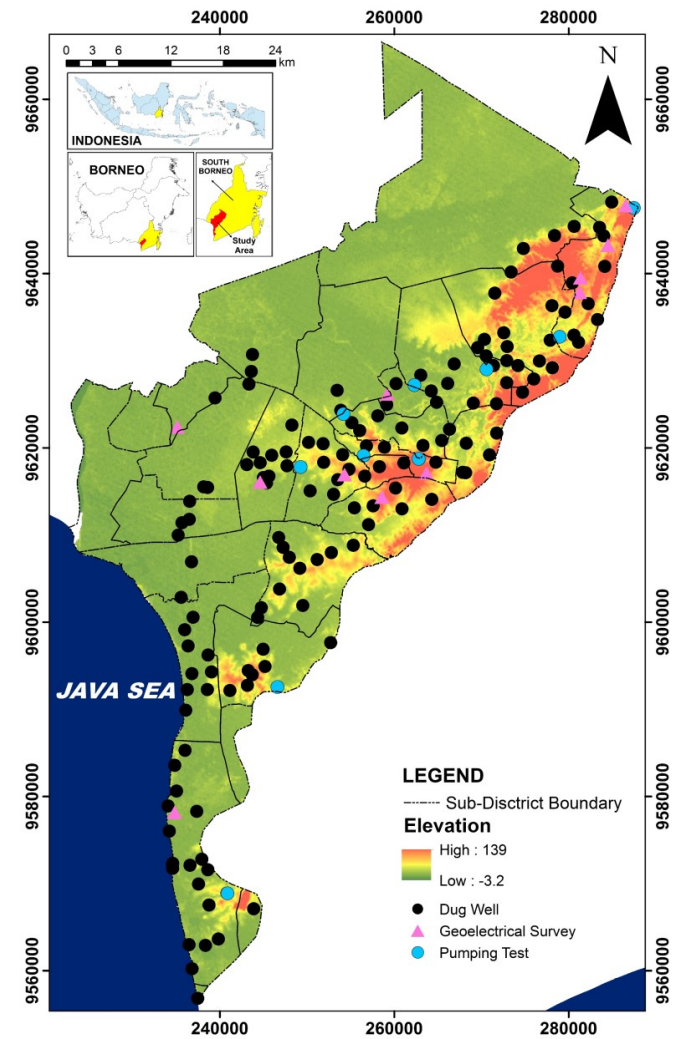

Figure 4. Elevation and POI map 


\section{Methods}

The DRASTIC method was used to systematically evaluate the vulnerability of groundwater to contaminants based on the existing information by prioritizing hydrogeological factors that influence groundwater movement.

This method (Aller et al., 1987) is based on seven hydrogeological parameters, namely depth to water table $(D)$, net aquifer recharge $(R)$, aquifer media $(A)$, soil media $(\mathrm{S})$, topography slope $(\mathrm{T})$, the impact of the vadose zone (I), and hydraulic conductivity of the aquifer (C). Calculating the net aquifer recharge of the study area considered the precipitation, evapotranspiration, and runoff, as each parameter had a weight depending on their support for pollution. Each parameter was divided into several classes, where each had a rating value. Table 3 shows the distribution of the DRASTIC index levels.

The value of each class and the weight of each parameter can be seen in Equation 2. The equation of the DRASTIC index is:
$\mathrm{DI}=\mathrm{Dw} \cdot \mathrm{Dr}+\mathrm{Rw} \cdot \mathrm{Rr}+\mathrm{Aw} \cdot \mathrm{Ar}+\mathrm{Sw} \cdot \mathrm{Sr}+\mathrm{Tw} \cdot \mathrm{Tr}+\mathrm{Iw} \cdot \mathrm{Ir}+\mathrm{Cw} \cdot \mathrm{Cr}$, where $D w$ is the weight of the depth to the water table, $D r$ is the rating of the depth to the water table, $\mathrm{Rw}$ is the weight of the net aquifer recharge, $\mathrm{Rr}$ is the rating of the net aquifer recharge, Aw is the weight of the aquifer media, Ar is the rating of the aquifer media, Sw is the weight of the soil media, $\mathrm{Sr}$ is the rating of the soil media, Tw is the weight of the topography slope, $\mathrm{Tr}$ is the rating of the topography slope, Iw is the weight of the impact of the vadose zone, Ir is the rating of the impact of the vadose zone, $\mathrm{Cw}$ is the weight of the hydraulic conductivity, and $\mathrm{Cr}$ is the rating of the hydraulic conductivity. The final results of the DRASTIC index vulnerability level were divided into five groups, namely very low, low, medium, high, and very high vulnerability (Civita and DeRegibus, 1995; Corniello et al., 1997; Juan et al., 2010).

NV index, one of the specific vulnerabilities adapted from the DRASTIC index, is an assessment of the level of vulnerability to nitrate pollution by considering land use (Juan et al., 2010). The rating value of the potential land use

Table 2. The weight and rating of the drastic index method (Aller et al., 1987)

\begin{tabular}{|c|c|c|c|}
\hline $\begin{array}{r}\text { Factor } \\
\end{array}$ & Detailed Aspect & Rating & Weight \\
\hline \multirow[t]{4}{*}{ Depth to water table (D) } & $0.04-1.15 \mathrm{~m}$ & 10 & 5 \\
\hline & $1.5-3 \mathrm{~m}$ & 9 & \\
\hline & $3-9 \mathrm{~m}$ & 7 & \\
\hline & $9-9.29 \mathrm{~m}$ & 5 & \\
\hline Net aquifer recharge $(R)$ & 248.1-253 mm/year & 8 & 4 \\
\hline \multirow[t]{4}{*}{ Aquifer media $(A)$} & Igneous Rock & 3 & 3 \\
\hline & Weathered Igneous & 4 & \\
\hline & Massive Limestone & 6 & \\
\hline & Sand and Gravel & 8 & \\
\hline \multirow[t]{4}{*}{ Soil media (S) } & Clay Loam & 3 & 2 \\
\hline & Loam & 5 & \\
\hline & Sandy Loam & 6 & \\
\hline & Aggregated Clay & 6 & \\
\hline \multirow[t]{5}{*}{ Topography slope (T) } & $>18 \%$ & 1 & 1 \\
\hline & $12-18 \%$ & 3 & \\
\hline & $6-12 \%$ & 5 & \\
\hline & $2-6 \%$ & 9 & \\
\hline & $0-2 \%$ & 10 & \\
\hline \multirow[t]{4}{*}{ Impact of the vadose zone (I) } & Silt/Clay & 1 & 5 \\
\hline & Shale & 3 & \\
\hline & Shale and Gravel with Significant Silt and Clay & 6 & \\
\hline & Limestone & 6 & \\
\hline \multirow{6}{*}{$\begin{array}{l}\text { Hydraulic conductivity of the aquifer } \\
\text { (C) }\end{array}$} & $0-0.86 \mathrm{~m} /$ day & 1 & 3 \\
\hline & $0.86-2.59 \mathrm{~m} / \mathrm{day}$ & 2 & \\
\hline & $2.59-6.05 \mathrm{~m} / \mathrm{day}$ & 4 & \\
\hline & $6.05-8.64$ m/day & 6 & \\
\hline & $8.64-17.18 \mathrm{~m} /$ day & 8 & \\
\hline & $>17.18 \mathrm{~m} /$ day & 10 & \\
\hline
\end{tabular}

Table 3. The vulnerability classification of the DRASTIC method (Aller et al., 1987)

\begin{tabular}{cc}
\hline DRASTIC Index & Vulnerability \\
\hline$<80$ & Very Low \\
$80-120$ & Low \\
$120-160$ & Moderate \\
$160-200$ & High \\
$>200$ & Very High \\
\hline
\end{tabular}


Table 4. Ranges and ratings applied to the potential risk associated with land use (LU) (Ministerio de Agricultura, 2005; Arauzo et al., 2008; Instituto Geologico y Minero de Espana, 2020; Heuer et al., 1999; Lin et al., 2000)

\begin{tabular}{cc}
\hline Land Use (LU) & Rating \\
\hline Irrigated field crops & 1 \\
urban areas & 0.8 \\
Non-irrigated field crops & 0.6 \\
Uncultivated land, semi-natural areas & 0.3 \\
Forests, natural areas & 0.2 \\
\hline
\end{tabular}

Table 5. Vulnerability classification to the NV index methods (Juan et al., 2010; Secunda et al., 1998)

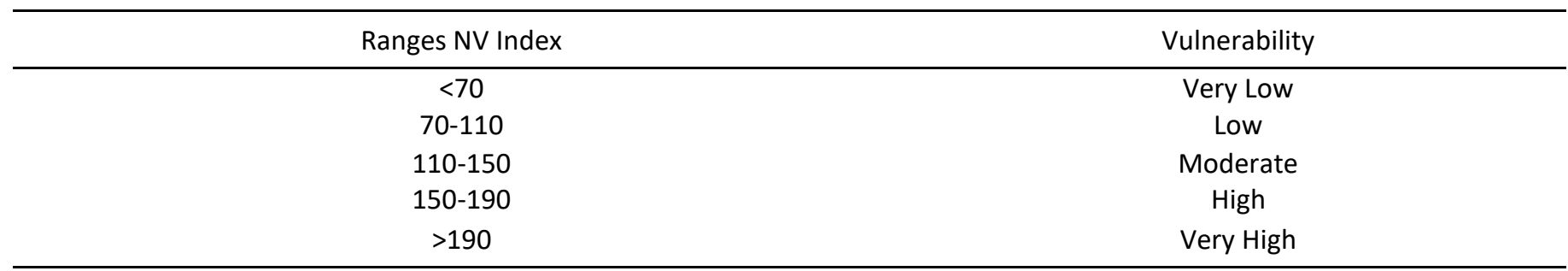

risk (LU) and the division of the NV index vulnerability level can be seen in Tables 4 and 5, respectively. The equation of $N V$ index is:

$\mathrm{NV}$ index $=(\mathrm{DI}) \times \mathrm{LU}$

Where LU is a potential risk associated with land use

\section{Result and Discussion}

Intrinsic Vulnerability using DRASTIC Index Method

Groundwater depth has a significant role in determining groundwater vulnerability (Meng et al., 2020) and affects the time pollutants take to pass through the unsaturated zone (Iqbal et al., 2015). Hence, the depth of the water table greatly affects the contaminants that enter the groundwater, as shallower areas are more susceptible.

In the study area, the depth to water table (D) was based on the measurements of 150 dug well points. As shown in Figure 5, the groundwater levels were between $0.04-9.29$ meters below the ground surface. The groundwater level is divided into four classes, and from the calculation, the location had a recharge $(R)$ value of 248.1-253.5 mm/year, as seen in Figure 6 and a rating of 8.

Figure 7 indicates that the aquifer media $(A)$ was divided into 5 classes, namely igneous rock (Mdb and Kypi), weathered igneous rock (Mgb), massive limestone, and/or sandstone (Kap, Kak, Tet, Tomb, Tmw, and TQd), sand, and gravel (Qa). In addition, soil types (S) above the unsaturated zone affects infiltration (Meng et al., 2020), as the presence of fine particles and organic microorganisms in the soil layer can reduce its permeability and impede pollutant migration (Posen et al., 2006; Rahman, 2008; Kowalska et al., 2018). As seen in Figure 8, the soil media composition in the study area comprised clay loam, loam, sandy loam, and clay aggregate.

Furthermore, topography $(T)$ or land slope affects the vulnerability to pollution by influencing the time the water stays above the ground and soaks up (Shekar and Pandey, 2015). Lower land slopes are characterized by longer residence and infiltration times, which facilitate the entry of contaminants and pollution of groundwater, causing the rating for land with low slopes to be high and vice versa. Figure 9 shows that the study area had a slope of $0-18 \%$ and was divided into five classes. Also, the vadose zone regulates the vertical migration of pollutants, such that the particles are finer or have less developed cracks, resulting in slower and longer duration of the pollutants' access to the aquifer (Min et al., 2019). The impact to vadose zone (I) is located above the groundwater level and correlates firmly with the aquifer media parameter. This similarity occurs because they represent the groundwater aquifer, not the surface, unlike the soil media parameter. The I zone is usually an impermeable layer of clay and silt, which greatly affects the rate of contaminant entry and pollution of groundwater. According to Figure 10, the analysis results show that the unsaturated zone is divided into four classes.

Hydraulic conductivity $(C)$ is the ability of rocks to allow the passage of water through their cavities without a change in physical properties. This parameter is determined by the type of rock, soil grain size, compactness, and grain composition and controls the hydraulic transport capacity of aquifers and pollutant flow (Shahab et al., 2019). As indicated by Figure 11, the hydraulic conductivity at the study area was divided into five classes.

Hydraulic conductivity $(\mathrm{C})$ is the ability of rocks to allow the passage of water through their cavities without a change in physical properties. This parameter is determined by the type of rock, soil grain size, compactness, and grain composition and controls the hydraulic transport capacity of aquifers and pollutant flow (Shahab et al., 2019). As indicated by Figure 11, the hydraulic conductivity at the study area was divided into five classes.

Consequently, the levels of groundwater vulnerability to contamination were obtained from the analysis of these seven parameters and divided into three groups, namely low, moderate, and high vulnerability, as presented by Figure 12.

The low vulnerability areas had a DRASTIC index value of 95-120, which means that they were only contaminated by certain pollutants disposed of continuously during a 


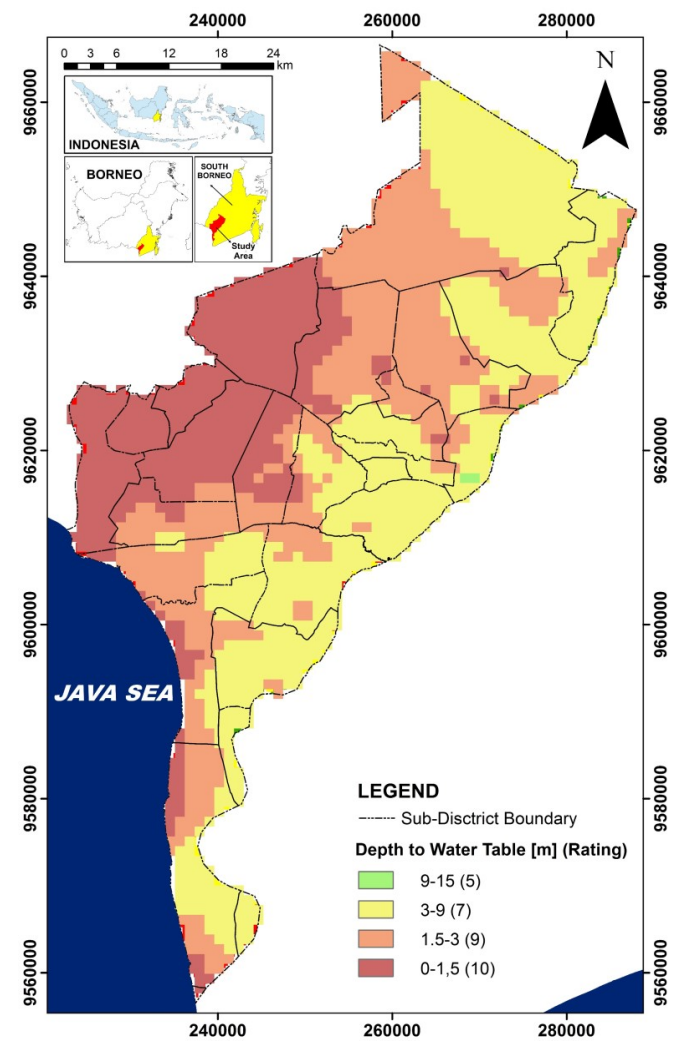

Figure 5. Map of the D parameter

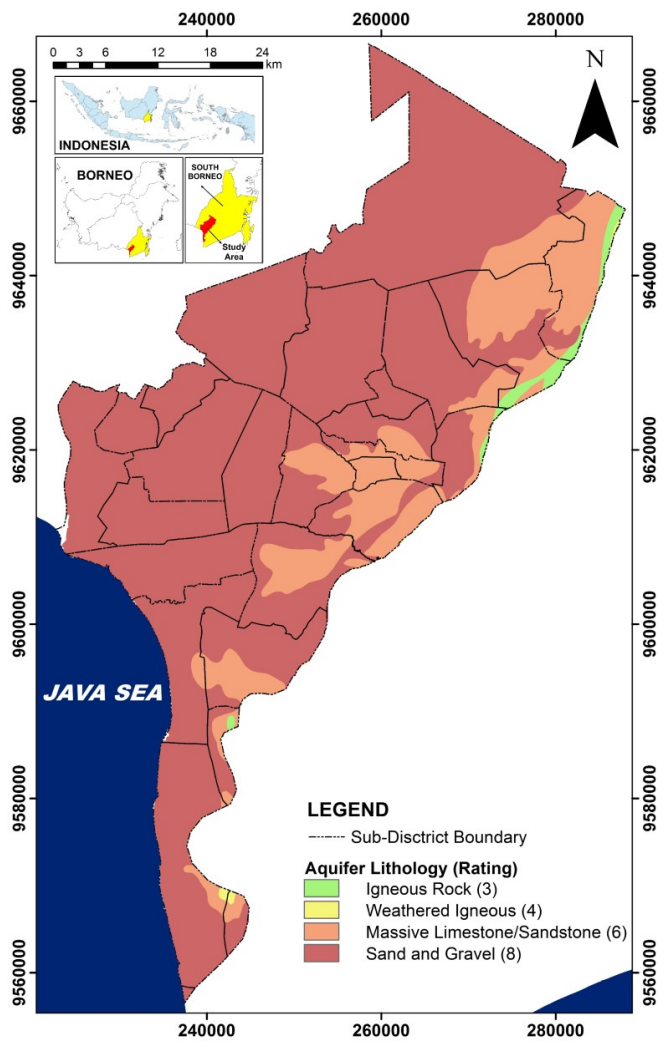

Figure 7. Map of the A parameter

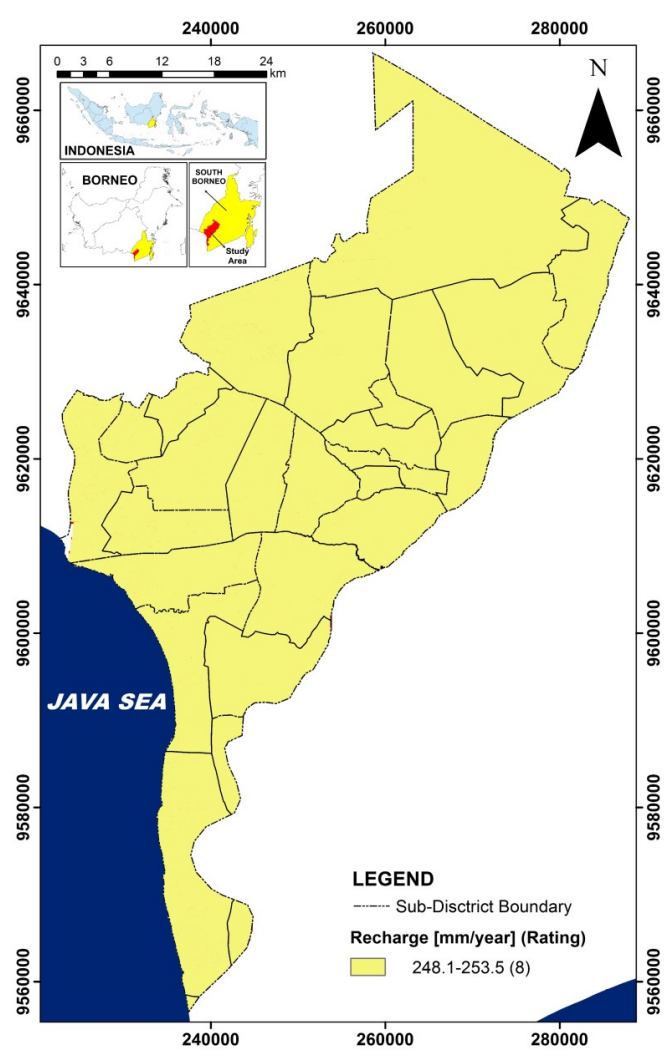

Figure 6. Map of the R parameter

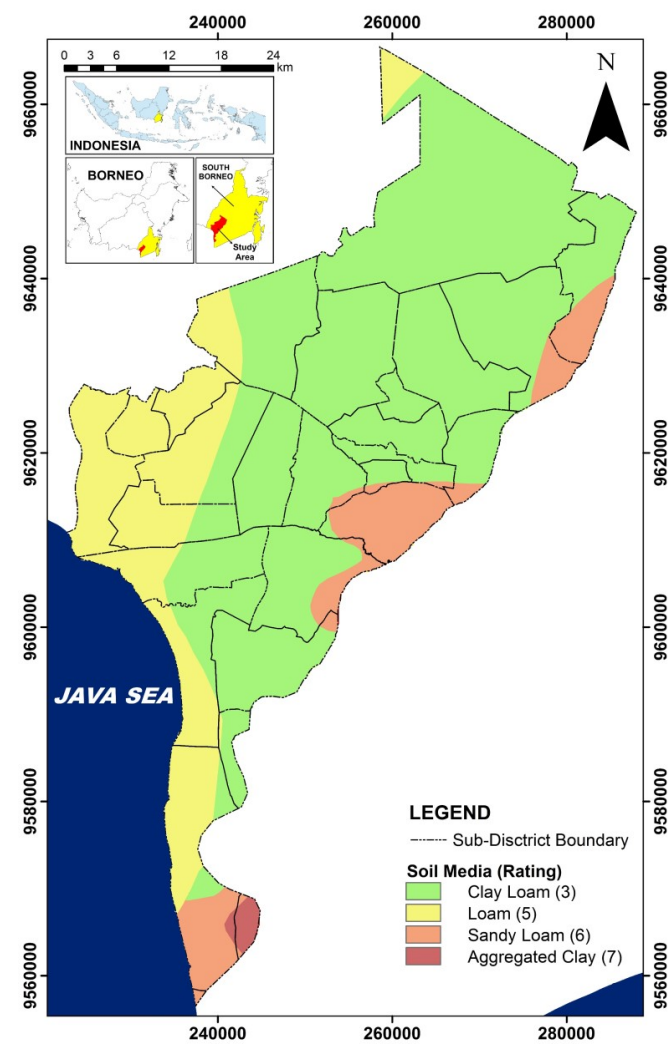

Figure 8. Map of the $S$ parameter relatively long period. Conversely, the moderate vulnerability zones had values of $120-160$, indicating the susceptibility to continuously disposed of contaminants. The DRASTIC index value of high vulnerability areas was 160-186, denoting vulnerability to all pollutants, except those that require high absorption and change easily.

Hydraulic conductivity $(\mathrm{C})$ is the ability of rocks to allow the passage of water through their cavities without a change in physical properties. This parameter is determined by the type of rock, soil grain size, compactness, and grain composition and controls the hydraulic transport capacity of aquifers and pollutant flow (Shahab et al., 2019). As indicated by Figure 11, the hydraulic conductivity at the study area was divided into five classes.

Consequently, the levels of groundwater vulnerability to contamination were obtained from the analysis of these 


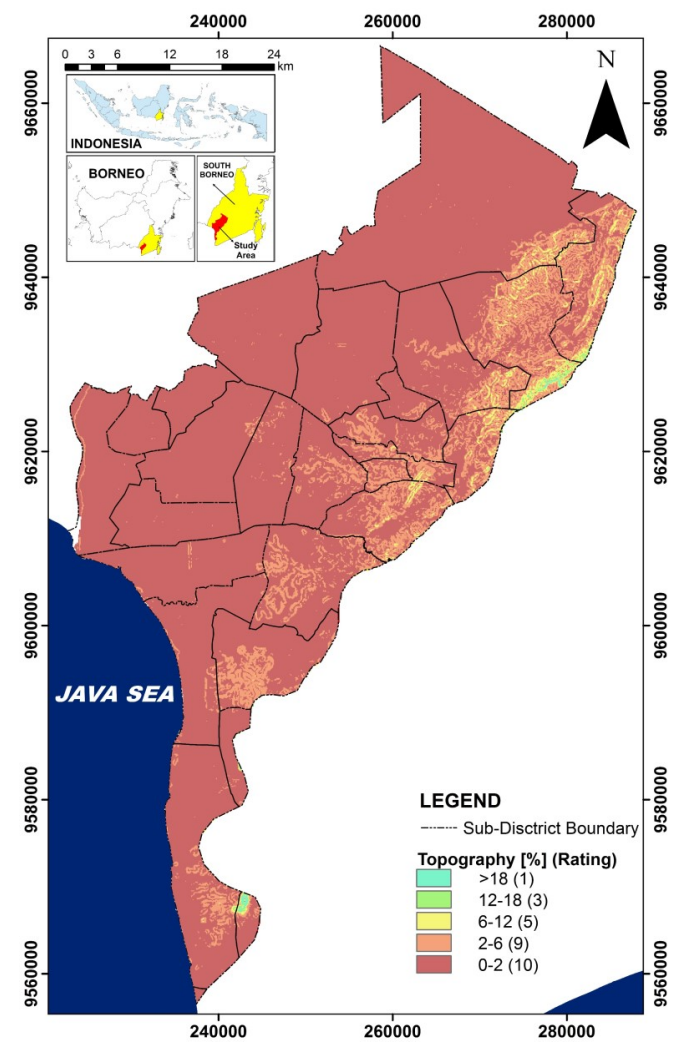

Figure 9. Map of the T parameter

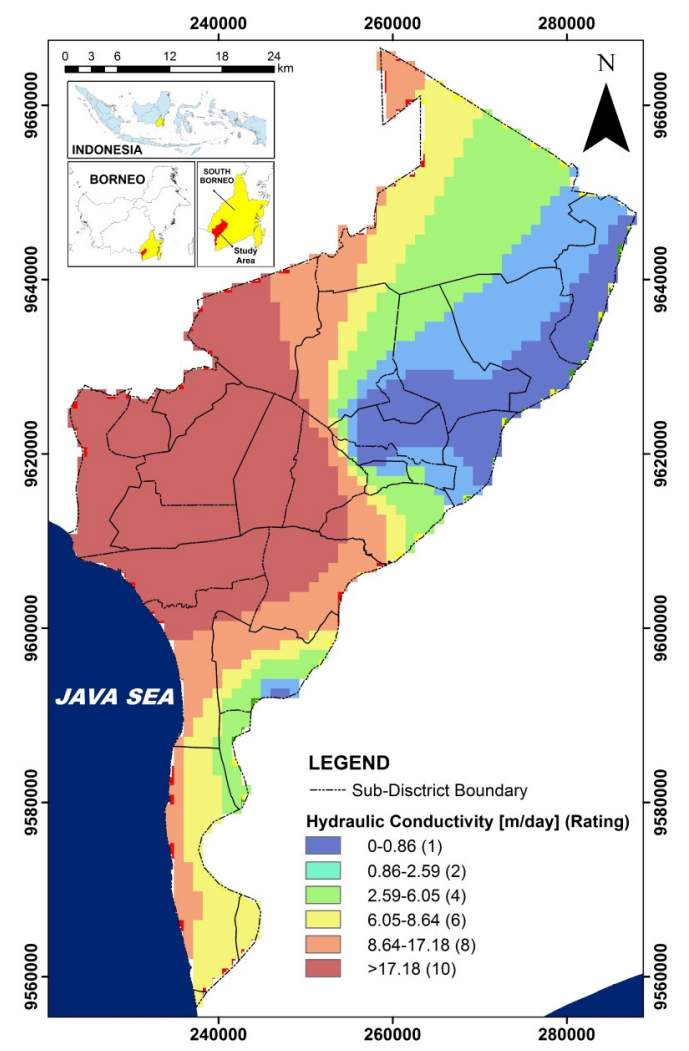

Figure 11. Map of the $\mathrm{C}$ parameter

seven parameters and divided into three groups, namely low, moderate, and high vulnerability, as presented by Figure 12.

The low vulnerability areas had a DRASTIC index value of 95-120, which means that they were only contaminated by certain pollutants disposed of continuously during a relatively long period. Conversely, the moderate vulnerability zones had values of $120-160$, indicating the

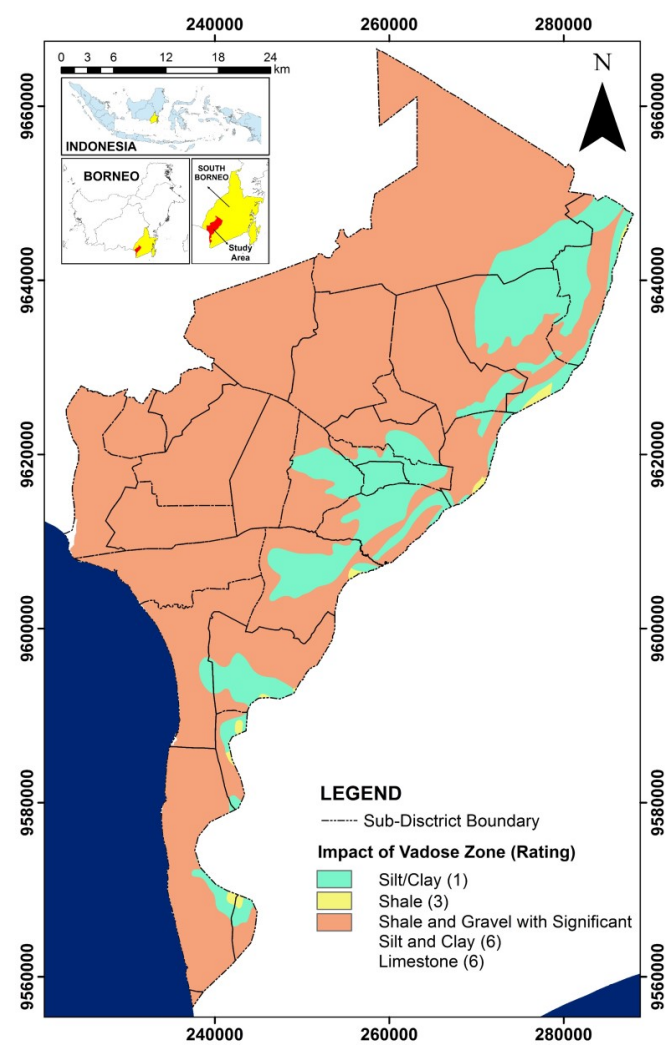

Figure 10. Map of the I parameter

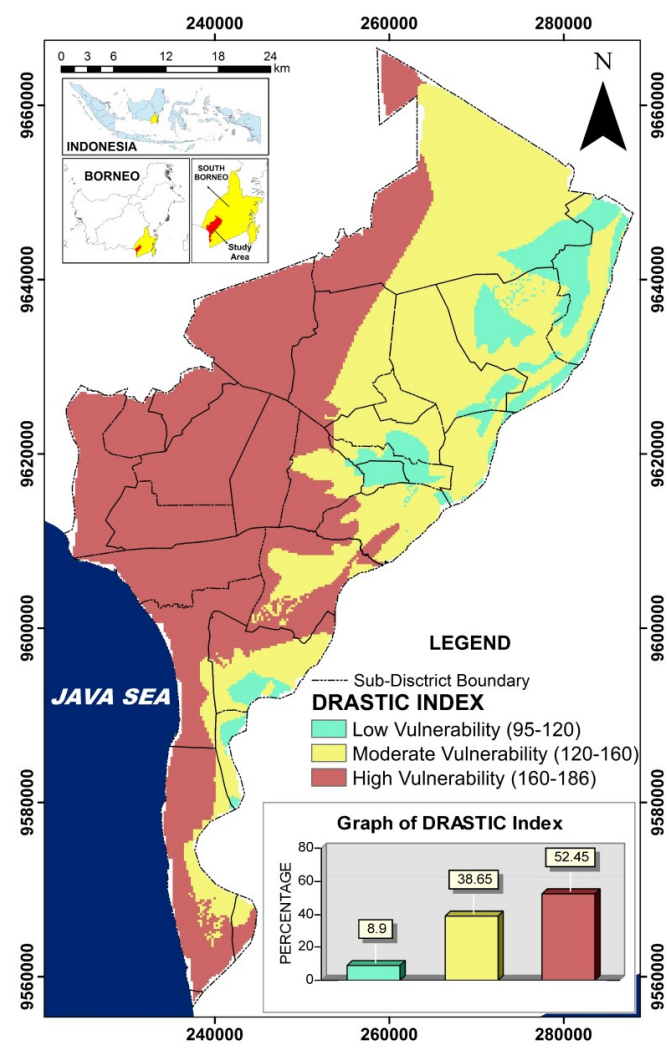

Figure 12. DRASTIC method result

susceptibility to continuously disposed of contaminants. The DRASTIC index value of high vulnerability areas was 160-186, denoting vulnerability to all pollutants, except those that require high absorption and change easily.

\section{Specific Vulnerability using NV Index Method}

Specific vulnerability can be related to land use by adding parameters, such as the weight value of 4 


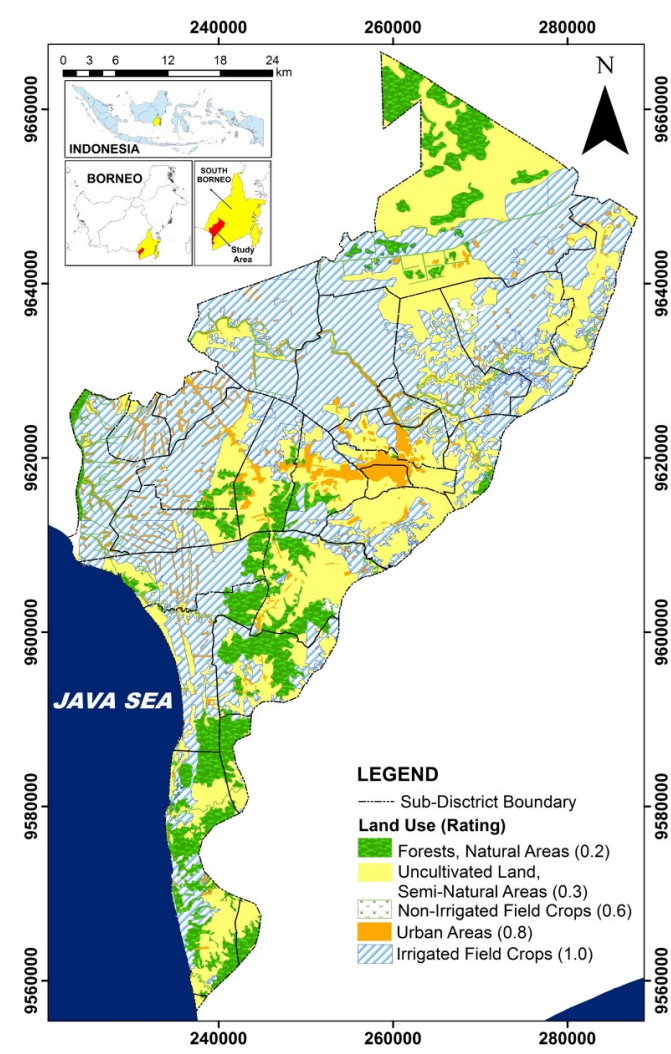

Figure 13. Potential risk map with land use vulnerability value (LU)

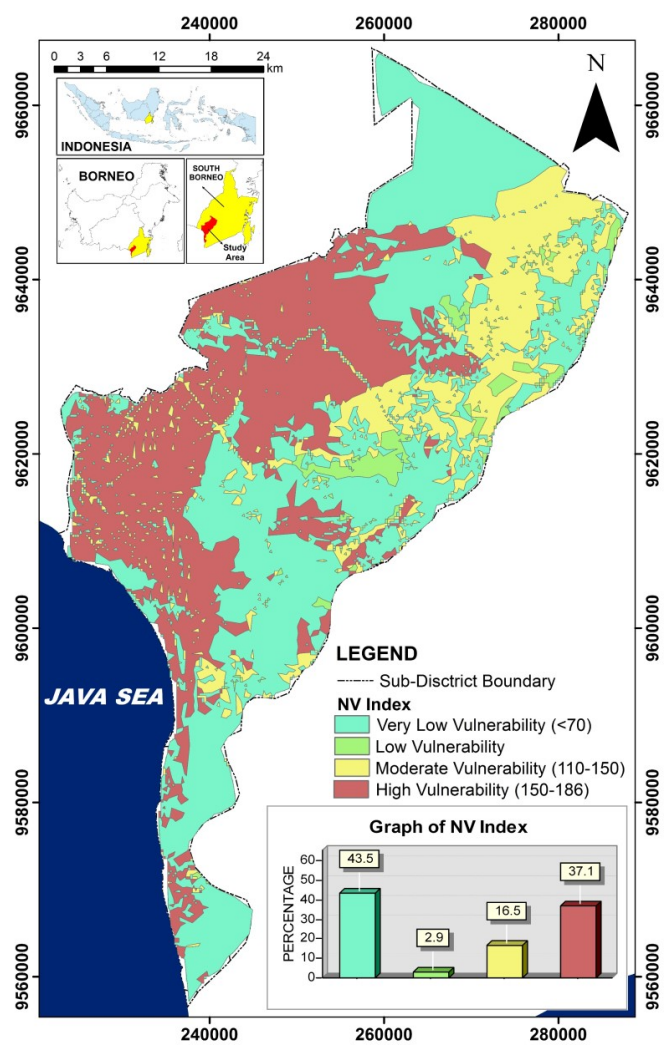

Figure 14. Groundwater vulnerability to contamination with the NV index
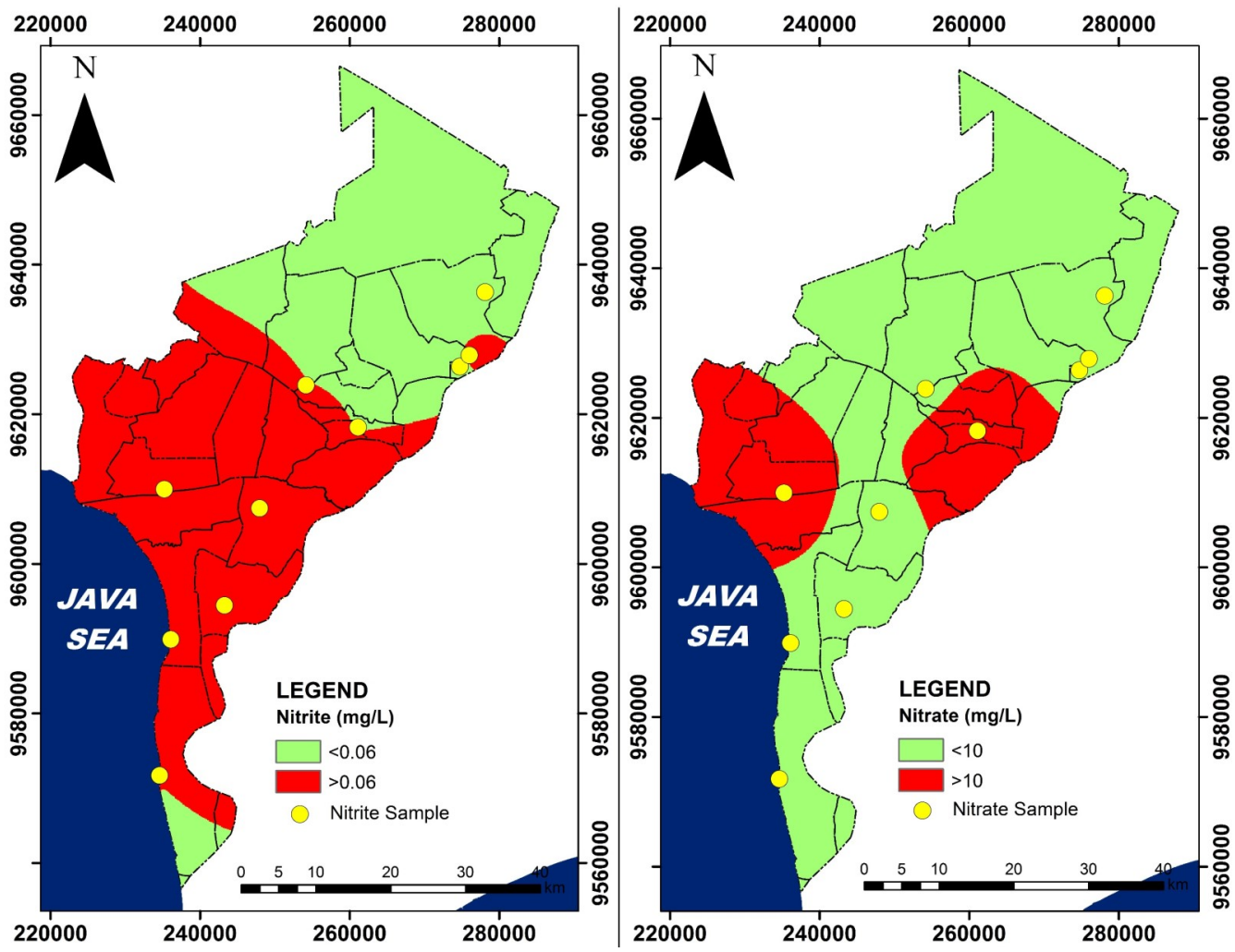

Figure 15. Groundwater quality map: (Left) distribution of nitrite and (Right) nitrate values in the study area based on the Indonesian Government Regulation No. 82 of 2001

(Widyastuti et al., 2006). Land use impacts groundwater pollution, such as through contamination via nitrate, obtained from the excessive use of pesticides on agricultural land.

Figure 13 describes the division of the study area into 4 , including natural areas, such as forests, swamps, and rivers, with a rating value of 1 . The second category is non-irrigated field crops land characterized by a rating value of 4 , uncultivated lands, such as shrubs, grasslands, and fields, with a rating value of 5 . Finally, urban areas and irrigated field crops land are defined by a rating of 8 .

The NV index analysis results show the division of groundwater vulnerability into four categories. These are very low/uncontaminated with a value of $21.2-70$, low 


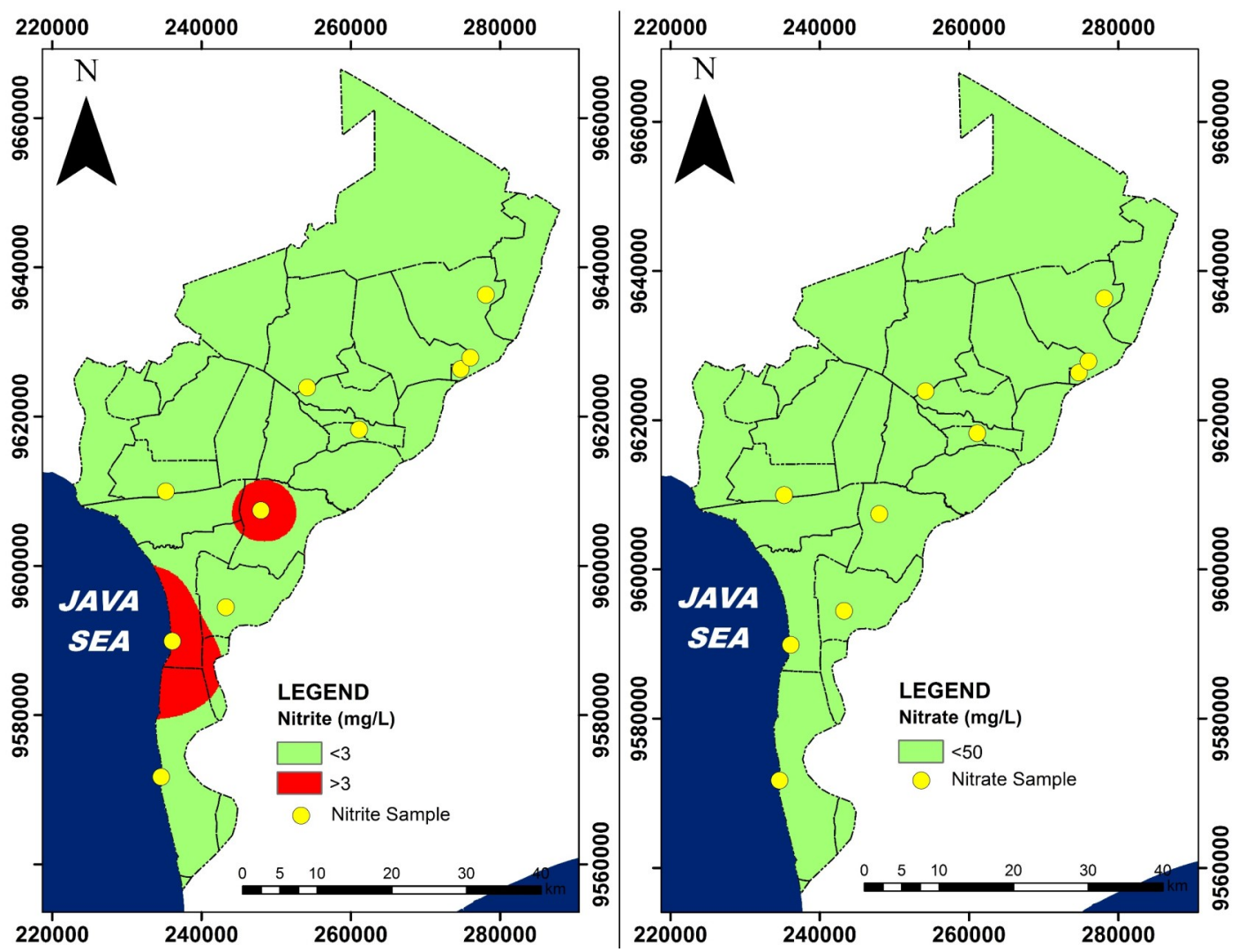

Figure 16. Groundwater quality map: (Left) distribution of nitrite and (Right) nitrate values in the study area based on the WHO's Guidelines of Drinking Water Qualities
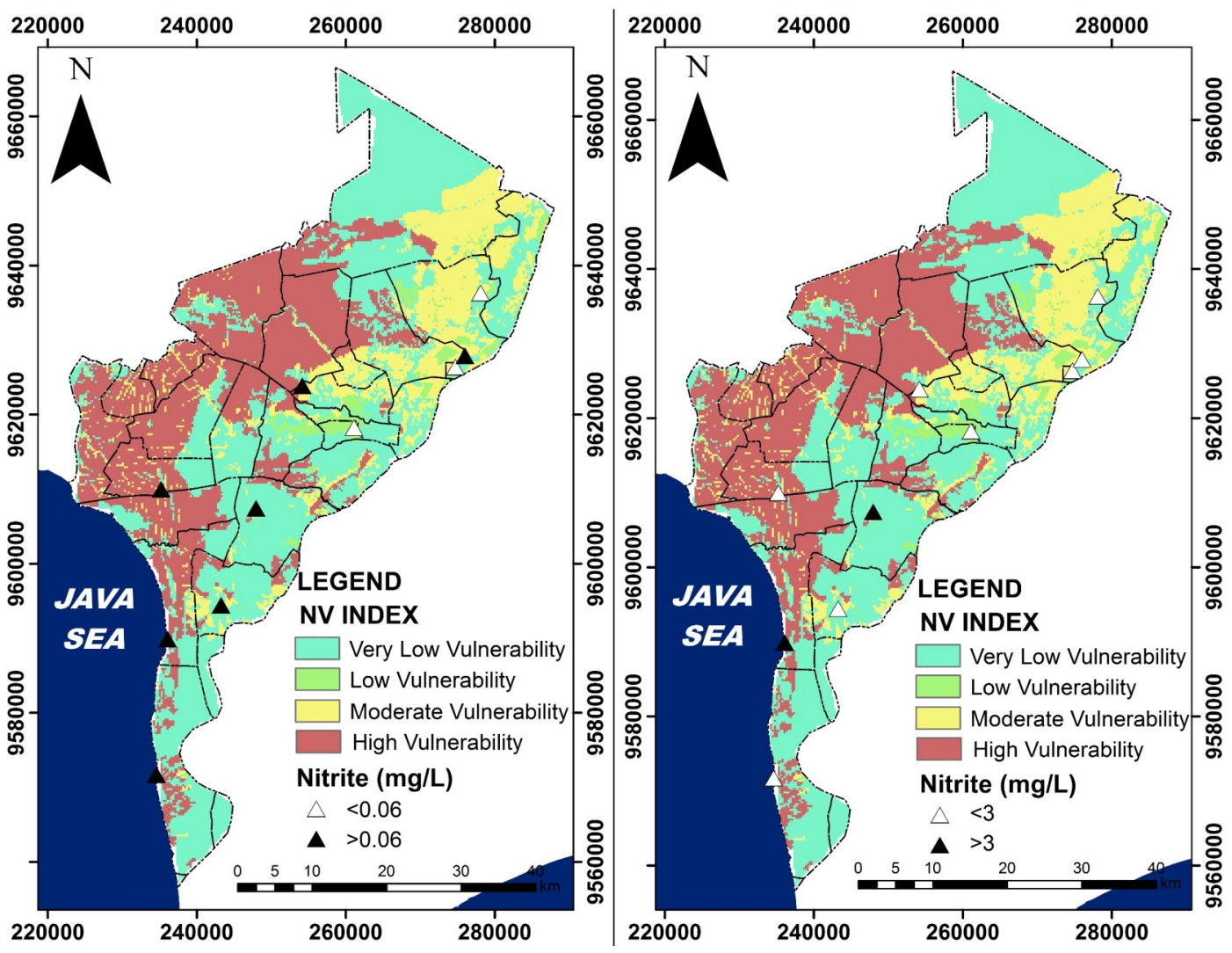

Figure 17. Groundwater vulnerability Validation map using the NV method with nitrite, based on (Left) Indonesian regulation and (Right) WHO regulation

vulnerability seen at $70-110$, moderate at $110-150$, and high vulnerability with a value of $150-186$, as depicted in Figure 14. The results further indicate that the areas with a high-level vulnerability are generally irrigated agricultural lands and settlements.
Groundwater Vulnerability to Contamination Validation

Groundwater vulnerability validation was conducted to determine the accuracy of the study method to pollution by comparing the results of assessments and water quality tests (Putranto and Marjuanto, 2021). 


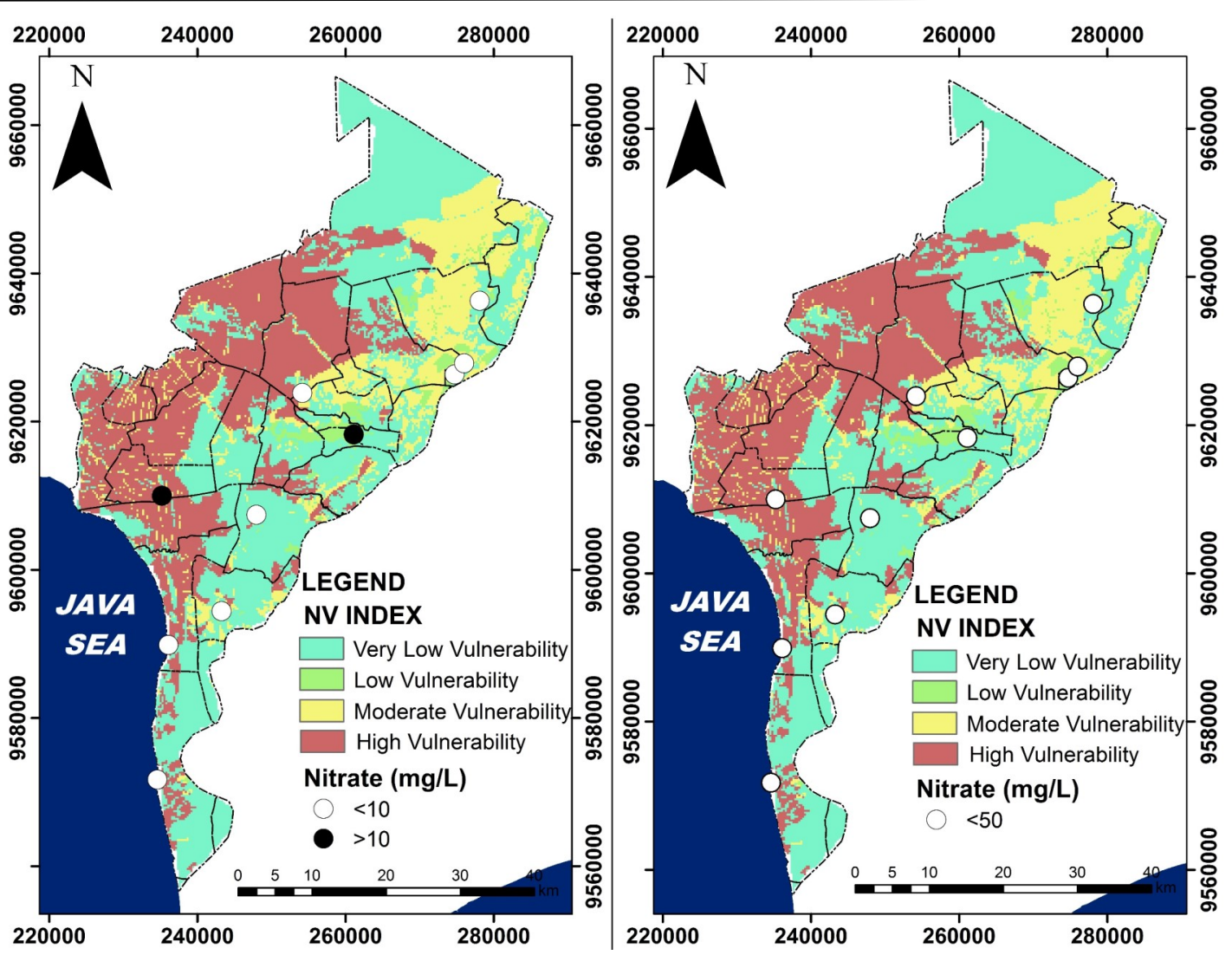

Figure 18. Groundwater vulnerability validation map using the NV method with nitrate, based on (Left) Indonesian regulation and (Right) WHO regulation

The water quality test parameters used were nitrate and nitrite, consisting of 10 units of groundwater samples, which were interpolated with the kriging method. Nitrates indicate contamination by anthropogenic activities, such as agricultural and household waste (Effendi, 2003; Sudarmadji, 2013; Prabowo and Dewi, 2016). Generally, nitrate and nitrite contamination of groundwater occurs due to the use of inorganic fertilizers, household and industrial waste, septic tank leakage, alongside waste from landfills (Prabowo and Dewi, 2016; Adimalla, 2019; Wei et al., 2017). Hence, the areas with highly developed land use comprising these activities in the study area will show this significant pattern.

The determination of the threshold values for nitrates and nitrites during the validation process is based on Indonesian Government Regulation No. 82 of 2001 concerning Water Quality Management \& Water Pollution Control and Guidelines for Drinking Water Qualities from the World Health Organization (WHO, 2011). The first regulation stipulates that the nitrite and nitrate contents for Class I quality standards do not exceed $0.06 \mathrm{mg} / \mathrm{L}$ and $10 \mathrm{mg} / \mathrm{L}$, respectively. Meanwhile, the second regulation fixed the standardized amount of nitrite and nitrate in groundwater at $3 \mathrm{mg} / \mathrm{L}$ and $50 \mathrm{mg} / \mathrm{L}$, respectively. Generally, the NV method is validated with nitrite and nitrate components, unlike the typical DRASTIC method, which cannot represent the anthropogenic causes validated through both tracers. By including land use conditions as one of the considerations, the NV method can apply these tracers. The distribution of nitrite and nitrate values in the study area based on the comparison between the first and second regulations with the NV method can be seen in Figures 15 and 16.
Based on the first regulation, the distribution of nitrite values in the study areas showed that 7 out of 10 samples $(70 \%)$ had concentrations $>0.06 \mathrm{mg} / \mathrm{L}$. The sites with high nitrate concentrations were in the middle of the location and extended to the south. Also, the nitrate distribution indicated that 2 out of the 10 samples (20\%) had concentrations $>10 \mathrm{mg} / \mathrm{L}$, which were localized in the western and eastern parts. Conversely, comparisons based on the second regulation revealed a decrease in the distribution of nitrite and nitrate in the study area due to the higher limit of components (maximum nitrate $=50 \mathrm{mg} / \mathrm{L}$, nitrite $=3 \mathrm{mg} / \mathrm{L}$ ). Hence, only 2 out of 10 samples $(20 \%)$ had nitrate content above the maximum, while none had excessive nitrate distribution.

The amount of nitrite and nitrate pollution in the groundwater was possibly caused by the close location of the dug wells to agricultural areas. Nitrogen compounds originating from the inappropriate use of urea fertilizers can be the reason, and the closeness of dug wells to rice fields may exacerbate nitrite contamination (Ganefati, 2005). According to the land use map in Figure 12, locations with high concentrations of nitrate and nitrite were majorly irrigated fields, uncultivated land, and semi-natural areas. The comparison of the sample distribution with regulationbased points overlayed with the NV vulnerability map is shown in Figures 17 and 18 below.

Meanwhile, the scatter graph in Figure 19 shows the NV index assessment of the groundwater vulnerability to nitrite levels and the variable tendencies of both regulations. The results show a good correlation for the positive tendency with very low to low vulnerabilities and below-limit nitrite and nitrate contents. The number of samples with NV value 


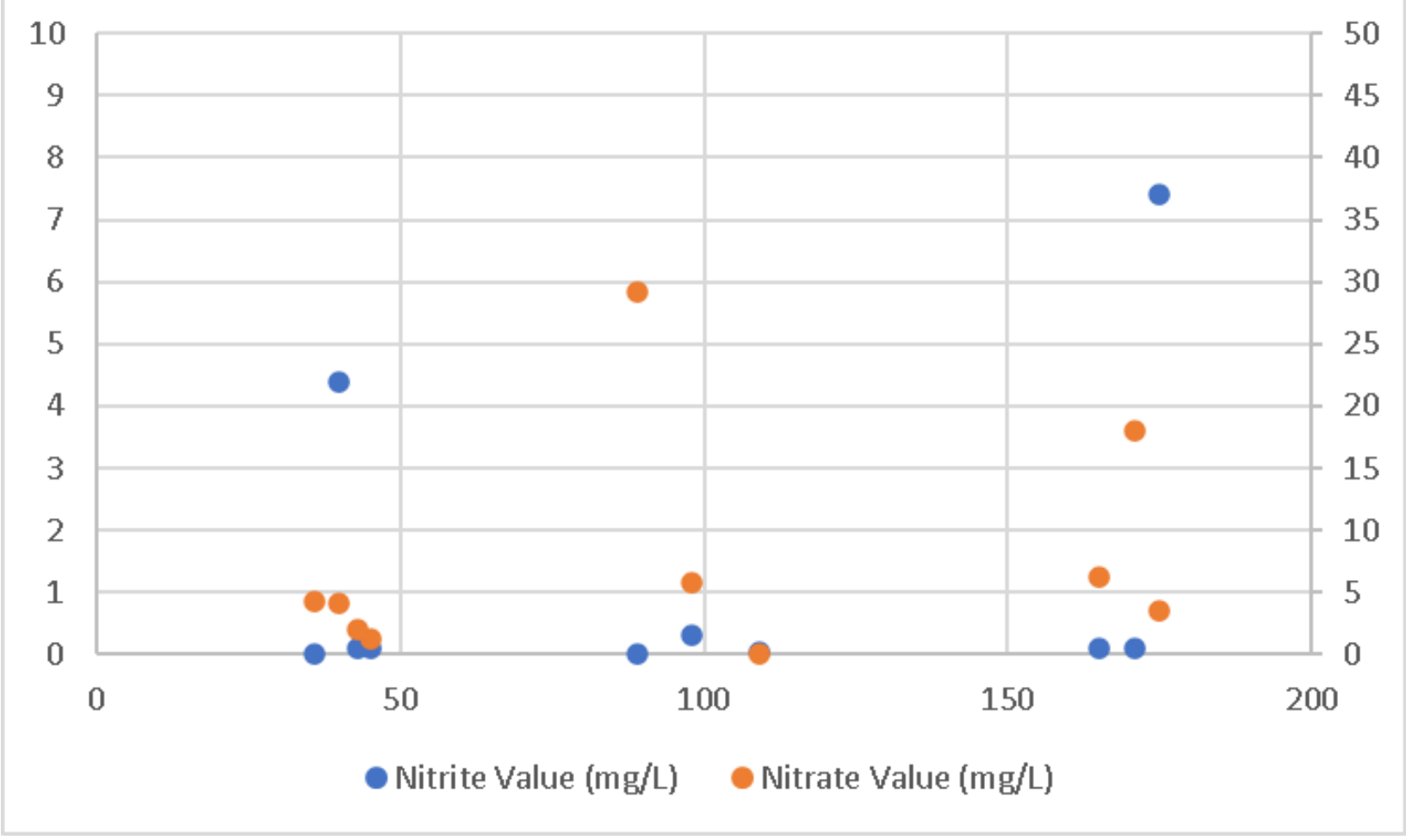

Figure 19. Scatter plot graph that showed the distribution relationship of NV value compared to nitrite and nitrate value

below 110 had a significant relationship with 6 out of 10 samples consisting of low nitrite and nitrate areas, based on the limits of the first regulation. According to the second regulation, 6 nitrite and 7 nitrate samples had positive correlations. Conversely, the negative tendencies of the high, medium to high vulnerability values with over-limit nitrite and nitrate contents had different correlations. Only 1 of the 10 samples had similar nitrite and nitrate patterns based on the first regulation, while 1 nitrite and zero nitrate correlated with the NV value in the second regulation.

\section{Comparisons to Other Related Studies}

Although numerous groundwater vulnerability assessment methods have been employed globally (Barbulescu, 2020), the typical DRASTIC technique and its development into the NV index or the nitrate-nitrite validation have been widely used. The combination of both methods can be applied in various conditions, such as different lithological, hydrogeological, hydrological, and geographical areas. Some of these studies have been conducted in tropical areas (Gupta, 2014; Snguon et al., 2010; Djémin et al., 2016), arid to semi-arid conditions (Oroji, 2018; Pourkhosravani et al., 2021; Ghazavi and Ebrahimi, 2015; Baghapour et al., 2016), cold regions or higher altitudes (Hasiniania et al., 2010), and even in a large region with variable geographical conditions (Ouedraogo et al., 2016). Meanwhile, the NV index in this study showed a positive correlation when traced intimately with nitritenitrate evaluations and variations of recent land use in the negative tendencies of high NV and nitrite-nitrate content on some occasions. The positive tendencies of the relationship between the two aspects of low vulnerability and nitrite-nitrate content also showed a better correlation than the negative tendencies.

\section{Conclusions}

The assessment of groundwater vulnerability to contamination depends on the conditions of the study area, such as groundwater depth, aquifer lithology, soil types above the aquifer, rainfall, slope, and hydraulic conductivity, and external factors such as land use. Hence, these assessments are expected to contribute to groundwater management in the future.

The results of the DRASTIC index evaluation in this study showed that the location is included in three vulnerability indexes, namely low (95-120), moderate (120-160), and high (160-186). Conversely, the NV method indicated four categories, namely very low (21.2-70), low (70-110), moderate (110-150), and high (150-186). Subsequently, specific vulnerabilities were regarded as more effective in determining the vulnerability index than the intrinsic technique. This is because of the consideration of land use, proven by tracing with nitrite and nitrate components. The differences in this aspect provide a broader picture of vulnerability indexes, specifically the relationship between nitrite-nitrate and the type of NV vulnerability result.

Based on the results obtained, this study suggests that specific attention should be paid to land management in areas with a high level of pollution resistance and vulnerability. Several actions can be taken to prevent pollution, including the limitation of groundwater use by employing alternatives such as surface water or rainwater (rain harvesting). In addition, groundwater quality conditions can be supervised by making regular monitoring wells to mitigate pollution. Based on the DRASTIC result, the generation of stricter local government policies is also suggested, such as limiting the exploitation of groundwater and conducting more comprehensive evaluations in the moderate to high vulnerability areas. The NV index results led to the recommendation that the government strengthen 
the policy for limiting or evaluating the usage of household or agricultural materials that can contaminate the shallow groundwater, specifically in moderate to high vulnerability areas. Furthermore, the local government should enforce diverse regional regulations for groundwater maintenance and exploitation based on the different vulnerabilities, as well as assess alternate water sources to fulfil society's needs.

\section{Acknowledgement}

The authors are grateful to the Energy and Mineral Resources Agency of the government of South Borneo for facilitating the field campaign, the hydrogeological study group of the Geological Engineering Department, and the Engineering Faculty of the Diponegoro University Indonesia. The authors are also highly thankful for the research funding from the Ministry of Technology and Research/National Innovation and Research Agency, the Republic of Indonesia, with contract no. 257-127/UN7.6.1/PP/2021.

\section{Reference}

Abdullahi, U. (2009). Evaluation of Models for Assessing Groundwater Vulnerability to Pollution in Nigeria. Bayero Journal of Pure and Applied Sciences, 2, 138-142.

Adimalla, N. (2019). Spatial Distribution, Exposure, and Potential Health Risk Assessment from Nitrate in Drinking Water from Semi-Arid Region of South India. Hum. Ecol. Risk Assess Int. J, $26,1-25$.

Alexander, A., Ndambuki, J., Salim, R., \& Manda, A. (2017). Assessment of Spatial Variation of Groundwater Quality in a Mining Basin . Sustainability, 9, 823.

Aller, L., Bennet, T., Lehr, J., \& Petty, R. (1987). DRASTIC: A Standardized System for Evaluating Ground Water Pollution Potential Using Hydrogeological Settings. New York: US EPA.

Arauzo, M., Martínez-Bastida., Juan, J., \& Valladolid, M. (2008). Nitrogen Pollution of the "River-Aquifer System" in the Jarama Basin (Comunidad de Madrid, Spain): Is it from agricultural or urban sources. Limnetica, 27, 195-210.

Baghapour, M., Nobandegani, A., Talebbeydokhti, N., Bagherzadeh, S., Nadiri, A., Gharekhani, M., \& Chitsazan, N. (2016). Optimization of DRASTIC Method by Artificial Neural etwork, Nitrate Vulnerability Index, and Composite Drastic Models to Assess Groundwater Vulnerability of Unconfined Aquifer of Shiraz Plain, Iran. Journal of Environmental Health Science and Engineering, 14, 13.

Barbulescu, A. (2020). Assessing Groundwater Vulnerability: DRASTIC and DRASTIC-Like Methods: A Review. Water, 12 (1356), pp. 1-22.

Civita, M., \& De Regibus, C. (1995). Testing Methodologies for Assessing Aquifer Vulnerability. Quad Geol Appl Pitagora Ed Bologna , 3, 63-71.

Corniello, A., Ducci, D., \& Napolitano, P. (1997). Comparison Between Parametric Methods to Evaluate Aquifer Pollution Vulnerability Using GIS: An Example in the "Piana Campana", Southern Italy. In: Marinos PG, Koukis GC, Tsiambaos GC, Stournaras GC (eds). . Engineering Geology and The Environmen, 1, 1721-1726.

Dassargues, A., \& Gogu, R. (2000). Current Trends and Future Challenges in Groundwater Vulnerability Assessment Using Overlay and Index Methods. Environmental Geology, 39, 549559.

Davraz, A. (2015). Evaluation of the Groundwater Quality with Wqi (Water Quality Index) and Multivariate Analysis: A Case Study of the Tefenni Plain (Burdur/ Turkey). Environ Earth Sci, 73, 1725-1744.

Djémin, J. K. (2016). Contribution of the Sensitivity Analysis in
Groundwater Vulnerability Assessing Using the DRASTIC Method: Application to Groundwater in Dabou Region (Southern of Côte d'Ivoire). Journal of Environmental Protection, 7, 129-143.

Effendi, H. (2003). Assessing Water Quality for Management of Water Resources and the Environment, 1st ed. Yogyakarta: Kanisius.

Ganefati, S., Istiqomah, S., \& Purwanto. (2005). Management of Drinking Water Wells for Household Aeration, Filtration and Disinfection. Jurnal Tekling, 6, 262-267.

Ghazavi, R., \& Ebrahimi, Z. (2015). Assessing groundwater vulnerability to contamination in an arid environment using DRASTIC and GOD models. Int. J. Environ. Sci. Technol., 1-15.

Gorelick, S., \& Zheng, C. (2015). Global Change and the Groundwater Management Challenge. Water Resour. Res., 51, 3031-3051.

Grappein, B., Lasagna, M., Capodaglio, P., Caselle, C., \& Luca, D. (2021). Hydrochemical and Isotopic Applications in the Western Aosta Valley (Italy) for Sustainable Groundwater Management. Sustainability, 13, 487.

Gu, B., Ge, Y., Chang, S., Luo, W., \& Chang, J. (2013). Nitrate in Groundwater of China: Sources and Driving Forces. Glob. Environ. Chang, 23, 1112-1121.

Gupta, N. (2014). Groundwater Vulnerability Assessment using DRASTIC Method in Jabalpur District of Madhya Pradesh. International Journal of Recent Technology and Engineering (IJRTE), 3(3), 36-43.

Hasiniaina, F., Zhou, J., \& and Guoyi, L. (2010). Regional assessment of groundwater vulnerability in Tamtsag basin, Mongolia using drastic model. Journal of American Science, 6(11), 68-78.

Hendrayana, H. (2011). Introduction to Groundwater Vulnerability to Pollution and Groundwater Pumping. Yogyakarta: Gadjah Mada University.

Heryanto, R., \& Sikumbang, N. (1994). Geological Map of the Banjarmasin Sheet, Kalimantan, scale. Bandung: Geological Study and Development Centre.

Heuer, K., Brooks, P., \& Tonnessen, K. (1999). Nitrogen Dynamics in Two High Elevation Catchments During Spring Snowmelt 1996. Rocky Mountains. Colorado. Hydrological Process, 13, 22032214.

IGME. (2020, July 8). Groundwater in Spain. Diambil kembali dari Instituto Geológico y Minero de España: http://aguas.igme.es/ igme/ publica/libro20/lib20.htm.

Iqbal, J., Gorai, A., Katpatal, Y., \& Pathak, G. (2015). Development of GIS-Based Fuzzy Pattern Recognition Modell Modified DRASTIC Modell for Groundwater Vulnerability to Pollution Assessment. Int. J. Environ. Sci. Technol , 12, 3161-3174.

Jahanshahi, R., \& Zare, M. (2016). Hydrochemical Investigations for Delineating Salt-Water Intrusion into the Coastal Aquifer of Maharlou Lake, Iran. Journal of African Earth Sciences, 121, 1629.

Juan, J., Bastida, M., Arauzo, M., \& Valladolid, M. (2010). Intrinsic and Specific Vulnerability of Groundwater in Central Spain: The Risk of Nitrate Pollution. Hydrogeology Journal, 18, 681-698.

Kesuma, D., Purwanto, P., Putranto., \& Rahmana, T. (2017). Factor Weighting in DRASTIC Modelling for Assessing the Groundwater Vulnerability in Salatiga Groundwater Basin, Central Java Province, Indonesia. 3rd International Conference of Planning in the Era of Uncertainty. Institute of Physics Publishing (IOP): Earth and Environmental Science, 70, 012008.

Konikow, L., \& Kendy, E. (2005). Groundwater Depletion: A Global Problem. Hydrogeol. J, 13, 317-320.

Kowalska, J., Mazurek, R., Gasiorek, M., \& Zaleski, T. (2018). Pollution Indices as Useful Tools for the Comprehensive Evaluation of the Degree of Soil Contamination-A Review. Environ. Geochem. Health., 40, 2395-2420.

Lasagna, M., Ducci, D., Sellerino, M., Mancini, S., \& De Luca, D. (2020). Meteorological Variability and Groundwater Quality: Examplesin Different Hydrogeological Settings.Water, 12, 1297. 
Lasagna, M., Mancini, S., \& De Luca, D. (2019). Aquifer Protection from Overexploitation: Example of Actions and Mitigation Activi-Ties Used in the Maggiore Valley (Asti Province, NW Italy). Geoingegneria Ambientale e Mineraria, 156, 30-38.

Li, R., \& Merchant, J. (2013). Modelling Vulnerability of Groundwater to Pollution Under Future Scenarios of Climate Change and Biofuels-Related Land Use Change: A Case Study in North Dakota, USA. Sci. Total Environ, 447, 32-45.

Lin, B., Sakoda, A., Shibasaki, R., Goto, N., \& Suzuki, M. (2000). Modelling a Global Biogeochemical Nitrogen Cycle in Terrestrial Ecosystems. Ecol Model, 135, 89-110.

Machdar, L., Zulfikar, T., Rinaldi, W., \& Alfiansyah, Y. (2018). Assessment of Groundwater Vulnerability Using DRASTIC Model and GIS: A Case Study of Two Sub-Districs in Banda Aceh City, Indonesia. Institute of Physics Publishing (IOP): Materials Science and Engineering, 334, 012032.

Maria, R. (2018). Comparative Studies of Groundwater Vulnerability Assessment. Institute of Physics Publishing (IOP): Earth and Environmental Science, 118, 012018.

Martinez-Bastida, J.J., Arauzo, M., \& Valladolid, M. (2010). Intrinsic and Specific Vulnerability of Groundwater in Central Spain: The Risk of Nitrate Pollution. Hydrogeology Journal, 18, 681-698.

Meng, L., Zhang, Q., Liu, P., He, H., \& Xu, W. (2020). Influence of Agricultural Irrigation Activity on the Potential Risk of Groundwater Pollution: A Study with Drastic Method in A SemiArid Agricultural Region of China. Sustainability, 12, 1954.

Miglietta, P., Toma, P., Fanizzi, F., De Donno, A., Coluccia, B., Migoni, D., . . . Serio, F. (2017). A Grey Water Footprint Assessment of Groundwater Chemical Pollution: Case Study in Salento (Southern Italy). Sustainability, 9, 799.

Min, L., Qi, Y., Shen, Y., Wang, P., Wang, S., \& Liu, M. (2019). Groundwater Recharge Under rrigated Agro-Ecosystems in the North China Plain: from A Critical Zone Perspective. J. Geogr. Sci, 29, 877-890.

Ministerio de Agricultura, Pesca y Alimentación. (2007) Nitrate Balance in Spanish Agricultural Systems in 2005. Secretaría General de Agricultura y Alimentación. Dirección General de Agricultura: Madrid, Spanyol.

Mohammad, A. (2017). Assessing the Groundwater Vunerability in the Upper Aquifers of Zarqa River Basin, Jordan Using DRASTIC, SINTACS and GOD Methods. Internasional Journal of Water Resources and Environmental Engineering, 9, 44-53.

Oroji, B. (2018). Assessing groundwater vulnerability by pollution mapping in Iran: Case study Hamadan - Bahar plain. Geofísica internacional, 57(3), 161-174.

Ouedraogo, I., Defourny, P., \& Vanclooster, M. (2016). Mapping the groundwater vulnerability for pollution at the pan African scale. Science of the Total Environment, 544, 939-953.

Palar, H. (2004). Heavy Metal Pollution and Toxicology, 1st ed. Jakarta: Rineka Cipta.

Papaioannou, A., Plageras, P., Dovriki, E., Minas, A., Krikelis, V., Nastos, P., . . Paliatsos, A. (2006). Groundwater Quality and Location of Productive Activities in the Region of Thessaly (Greece). Desalination, 213, 209-217.

Posen, P., Lovett, A., Hiscock, K., Evers, S., Ward, R., \& Reid, B. (2006). Incorporating Variations in Pesticide Catabolic Activity into A GIS-Based Groundwater Risk Assessment. Sci. Total Environ, 367, 641-652.

Pourkhosravani, M., Jamshidi, F., \& Sayari, N. (2021). Evaluation of groundwater vulnerability to pollution using DRASTIC, composite DRASTIC, and nitrate vulnerability models. Environmental Health Engineering and Management Journal, 8 (2), 129-140.

Prabowo, R., \& Dewi, N. (2016). Nitrite Content on Well in Meteseh Village, Tembalang Sub-District, Semarang City. Journal of Scientific Biology, 5, 1-15.

Putranto, T., \& Kuswoyo, B. (2008). Groundwater Vulnerability Zone to Contaminant Using the DRASTIC Method. TEKNIK, 29, 0852-1697.
Putranto, T., \& Marjuanto, A. (2021). Assessment of Contamination Vulnerability of Groundwater Using Susceptibility Index Method: Semarang City as Case Study. Journal of Engineering Science and Technology, 16(1), 438-454

Putranto, T., \& Syah, M. (2018). Determining the Groundwater Vulnerability Using the Aquifer Vulnerability Index (AVI) in the Salatiga Groundwater Basin in Indonesia. AIP Conference Poceedings, 030016-1-030016-8.

Putranto, T., Widiarsi, D., \& Yuslihani, F. (2016). Study of Groundwater Vulnerability to Contaminant Using the DRASTIC Method in Pekalongan City. TEKNIK, 37, 26-31.

Rahman, A. (2008). A GIS-based DRASTIC Modell for Assessing Groundwater Vulnerability in the Shallow Aquifer in Aligarh, India. Appl. Geogr, 28, 32-53.

Saatsaz, M., Eslamian, S., \& Sulaiman, W. (2011). GIS DRASTIC Model for Groundwater Vulnerability Estimation of AstanehKouchesfahan Plain, Northern Iran. International Journal of Water, 6, 1-14.

Sadashivaiah, C., Ramakrishnaiah, R., \& Ranganna, G. (2008). Hydrochemical Analysis and Evaluation of Groundwater Quality in Tumkur Taluk, Karnataka State, India. International Journal of Environmental Research and Public Health, 5, 158-164.

Secunda, S., Collin, M., \& Melloul, A. (1998). Groundwater Vulnerability Assessment Using A Composite Model Combining DRASTIC with Extensive Agricultural Landuse in Israel's Sharon Region. Journal Environ Manage, 54, 39-57.

Sener, E., Sener, S., \& Davraz, A. (2009). Assessment of Aquifer Vulnerability Based on GIS and DRASTIC Methods: A Case Study of the Senirkent-Uluborlu Basin (Isparta, Turkey). Hydrogeol Journal, 17, 2023-2035.

Shahab, A., Shihua, Q., Rad, S., Keita, S., Khan, M., \& Adnan, S. ( 2019). Groundwater Vulnerability Assessment Using GISBased Drastic Method in the Irrigated and Coastal Region of Sindh Province, Pakistan. Hydrol. Res, 50, 319-338.

Shekhar, S., \& Pandey, A. (2015). A GIS-Based DRASTIC Modell for Assessing Groundwater Vulnerability in Hard Rock Granitic Aquifer Arab. J. Geosci, 8, 1385-1401.

Snguo, L., Putra, D., \& Hendrayana, H. (2010). Groundwater Vulnerability of Pandak and Bambanglipuro, Yogyakarta Special Province, Indonesia. J. SE Asian Appl. Geol., 2(2), 121-128.

Sorlini, S., Palazzini, D., Sieliechi, J., \& Ngassoum, M. (2013). Assessment of Physical-Chemical Drinking Water Quality in the Logone Valley (Chad-Cameroon). Sustainability , 5, 3060-3076.

Sudarmadji. (2013). Spring: Hydrological and Environmental Perspective, $1^{\text {st }}$ ed. Yogyakarta: Sekolah Pascasarjana UGM.

Taylor, R., Scanlon, B., Döll, P., Rodell, M., Van Beek, R., Wada, Y., . . . Edmunds, M. (2013). Groundwater and Climate Change. Nat. Clim. Chang, 3, 322-329.

van Zuidam, R. (1983). Guide to Geomorphology Aerial Photographic Interpretation and Mapping. . Netherlands: Department of Geomorphology and Geography, ITC.

Wei, Y., Fan, W., \& Wang, W. (2017). Identification of Nitrate Pollution Sources of Groundwater and Analysis of Potential Pollution Paths in Loess Regions: A Case Study in Tongchuan Region, China. Environ. Earth Sci, 76, 423.

WHO. (2011). Guideline for Drinking-Water Quality, Fourth Edition. United States of America: WHO Library Catalouging-inPublicating Dat.

Widyastuti, M., Notosiswoyo, S., \& Anggayana, K. (2006). Development of Methods "DRASTIC" for The Prediction of Groundwater Vulnerability to Contamination in Sleman. MGI, 20, 32-51. 